\title{
A NEW SPECIES OF IBEROBATHYNELLA SCHMINKE, 1973 (SYNCARIDA, BATHYNELLACEA, PARABATHYNELLIDAE) IN THE SOUTH OF THE IBERIAN PENINSULA
}

\author{
A.-I. Camacho
}

\begin{abstract}
A new Iberian species of the genus Iberobathynella is described from a well and a river bank, in the south of Spain (Andalusia).

The new species belongs to the subgenus Espanobathynella, comprising 5 species. This subgenus, to date, was known only from North Spain (Asturias, Cantabria and Burgos).

The new species presents a unique combination of characters, as follows: antennule with 7 segments; labrum with 8 main teeth; 8 teeth on the pars incisiva and 6-9 teeth on the pars molaris of the mandible; 7 teeth on the distal segment of the maxillule; maxilla with 1, 4 and 15 setae on its three segments, respectively; 7-10 spines on the furca; 7-11 spines on the sympod, 4 barbed setae on the exopod and 2 barbed and 1 plumose setae on the endopod of the uropod, and a pronounced anal operculum. The new species shows three characters which are unique in the subgenus: pronounced anal operculum; 3 setae on the endopod of the uropod, and 8 teeth on the pars incisiva of the mandible.
\end{abstract}

Keywords: Taxonomy, Crustacea, Iberobathynella, groundwater, Iberian Peninsula.

\section{Resumen}

Nueva especie de Iberobathynella Schminke, 1973 (Syncarida, Bathynellacea, Parabathynellidae) del sur de la península Ibérica

Se describe una nueva especie del género Iberobathynella encontrada en un pozo y en el medio intersticial de un río de la cuenca del Guadalquivir (Andalucia). Este género, endémico de la Península Ibérica, cuenta en la actualidad con 22 especies. En cuanto a diversidad, dentro de los Syncarida, sólo lo supera el género Hexabathynella, cosmopolita, con 23 especies.

La nueva especie pertenece al subgénero Iberobathynella (Espanobathynella) compuesto por 5 especies contando ésta. Este subgénero sólo se había encontrado hasta la fecha en el norte de España (en tres áreas muy pequeñas de Asturias, Cantabria y Burgos) y siempre en agua subterránea de cuevas.

La nueva especie no presenta estados de carácter desconocidos para el género, aunque la combinación de caracteres es única dentro del grupo: la anténula tiene 7 segmentos; el labro tiene 8 dientes principales; la mandíbula tiene 8 dientes en la pars incisiva -carácter único dentro del subgénero donde se conocían un máximo de 7 dientes, y habitual en el subgénero Iberobathynella (Iberobathynella) - y entre 6 y 9 en la pars molaris; la maxílula muestra 7 dientes en el segmento distal; la maxila tiene 1, 4 y 15 sedas, respectivamente, en sus tres segmentos; los toracópodos son similares a los de las demás 
especies del subgénero; el simpodio del urópodo muestra 7-11 espinas, con la distal enorme (dobla la longitud de las demás), tiene 4 sedas ciliadas en el exopodio y 2 sedas ciliadas largas y una pinnada, larga también, en el endopodio; este combinación de sedas es única en el subgénero y es muy poco frecuente encontrarla en otras especies del subgénero I. (Asturibathynella) -p.e. en I. (A.) celiana- mientras que es lo común entre las 5 especies del tercer subgénero, I. (Iberobathynella). El opérculo anal es sobresaliente, carácter único en el subgénero.

Palabras clave: Taxonomía, Crustacea, Iberobathynella, agua subterránea, península Ibérica.

\section{Introduction}

The tribe Iberobathynellini (Camacho and Serban, 1998) comprised 26 species up to now in the Iberian Peninsula, plus four in the rest of the world (three in North America and one in North Africa). This makes it the most diverse group of the family Parabathynellidae (Crustacea, Syncarida, Bathynellacea) (Camacho \& Serban, 2000; Camacho 2003a, b, 2005a, b, 2006).

The new species described herewith belongs to the genus Iberobathynella Schminke, 1973 (with 22 species) (see table 1), and to the subgenus Espanobathynella Camacho et Serban, 1998 (with five species).

This is the first time that Espanobathynella is found in Andalusia. This subgenus was the least diversified of the genus but now, with five species, is as diverse as I. (Iberobathynella). The discovery increases the limited distribution of the subgenus: from the Eastern part of Asturias, Cantabria and North of Burgos to South Spain (Andalucía). Only two species of Iberobathynella, I. (I.) paragracilipes Camacho \& Serban, 1998 and I. (Asturibathynella) celiana Camacho, 2003, were known from this area.

\section{Methods}

The material was collected with a $0.1 \mathrm{~mm}$ Ctetkov phreatobiological net (Cvetkov, 1968) from on artificial well, and from a river bank (interstitial environment) using the KaramanChappuis method (see Camacho, 1992).

All specimens comprising the type series were completely dissected and kept as permanent preparations (special metal slides, glycerine gelatine stained with methylene blue as mounting medium). Anatomical examinations were performed using an oil immersion lens (100X). The descriptions are based on the type series. The material is deposited in the Museo Nacional de Ciencias Naturales, Madrid (MNCN).

\section{Systematic account}

Genus Iberobathynella Schminke, 1973

Subgenus Espanobathynella Camacho et Serban, 1998 enmend.

Diagnosis: Pars incisiva of mandible (Md.) with 4-8 teeth, and dentate lobe (proximal endite or pars molaris) with 6-8 claws. Maxillule (Mx.I) with seven teeth on the distal endite. Maxilla (Mx.II) with one seta on proximal segment. Thoracopods (Ths): Exopod (Exp.) of first pair bi or uni-segmented, with four and three setae, respectively; bi-segmented in other pairs, with four setae. Thoracopod 8 (Th 8 ) male: external lobe with rectangular lateral face and with a sloping main axis. Uropod: sympod with 7-13 spines; endopod (endp.) with one or three setae or without setae; exopod (exp.) with 4-5 barbed setae. Furca with 710 spines. Anal operculum pronounced or not.

TyPe SPECIES: I. (E.) espaniensis Serban et Comas i Navarro, 1978.

SpeCIES: I. (E.) espaniensis Serban et Comas i Navarro, 1978; I. (E.) magna Camacho et Serban, 1998, I. (E.) cantabriensis Camacho et Serban, 1998, I. (E.) burgalensis Camacho, 2005 and I. (E.) andalusica n. sp.

\section{Iberobathynella (Espanobathynella) andalusica n. sp.} (figures 1 to 3)

Material eXAmined. Well at Fuentes de Andalucía (route NIV, Écija- Carmona, Sevilla) (type locality). Collected by A. G. Valdecasas and J. Rodríguez (29 December, 2004) three males and eight females. Additionally gathered 14 specimens, nine 
females and five males, in gravel bank of Varas river (route CV 217, Adamuz to Pozo Blanco, Córdoba) (Coordinates X: 356946, Y: 4216295, Z: 227 m), collected by A.G. Valdecasas, A. I. Camacho and C. Puch (7 November, 2006). Type series comprising male holotype (MNCN 20.04/7966) (Figure 1) and ten paratypes (MNCN 20.04/7967).

DiAGNOSIS: anal operculum pronounced; three setae on the endopod of the uropod, and 8 teeth on the pars incisiva of Md.

DESCRIPTION. Body total length of males 1.46$1.85 \mathrm{~mm}$ (holotype $1.85 \mathrm{~mm}$ ); of females 1.28-1.94 $\mathrm{mm}$ (see Figure 1). Body elongated, somites progressively wider towards posterior end of body. Head subquadrate.

Antennule (A.I) (figure 2A) 7-segmented, not sexually dimorphic; first four segments combined twice longer than last three combined; setation as in figure $2 \mathrm{~A}$ (segment 5 with two aesthetascs; segments 5 and 6 each with three aesthetascs). Antenna (A.II) (figure 2B) 3-segmented, last segment longest, with two smooth and one plumose terminal setae, and a small, shorter seta midway; first two segments without setae. Labrum (Lb.) (figure 2C) with eight main teeth, and two lateral teeth at each site. Mandible (Md) (figure 2D) pars incisiva with eight well-developed teeth; pars molaris with six teeth, distal five strong whereas proximal slender and bifid; all teeth densely setulose; mandibular palp almost exceeding pars incisiva in length. Maxillule (Mx.I) (figure 2E) proximal endite with four unequal spines; distal endite with seven teeth, most distant two smooth, rest denticulate; three smooth setae subterminally on outer distal margin. Maxilla (Mx.II) (figure 2F): 3 -segmented, with one seta on proximal segment; segment 2 with two long and one shorter setae distally, plus one additional ventral seta on inner margin; segment 3 elongated, with 15 setae. Thoracopods 1-7 (Th.1-Th.7) (figure 3A to 3G): well-developed, gradually increasing in length from 1 to 5 (figure $3 \mathrm{~A}$ to $2 \mathrm{E}$ ), last three similar in size; well-developed epipodite on 2 to 7 , not measuring more than half length of basipod; basipod with one seta on outer distal angle. Thoracopod 1 (figure 3A): short, exopod 1-segmented in all completely developed specimens, with three setae and with ctenidia on distal margin of segment; endopod 4-segmented: first segment with two smooth ventral setae, second with two smooth and one plumose setae, third with two setae, one small and smooth and other tiny; terminal segment with two claws of different length and one seta. Thoracopods 2 to 7 (figure 3B to 3G): exopod 2-

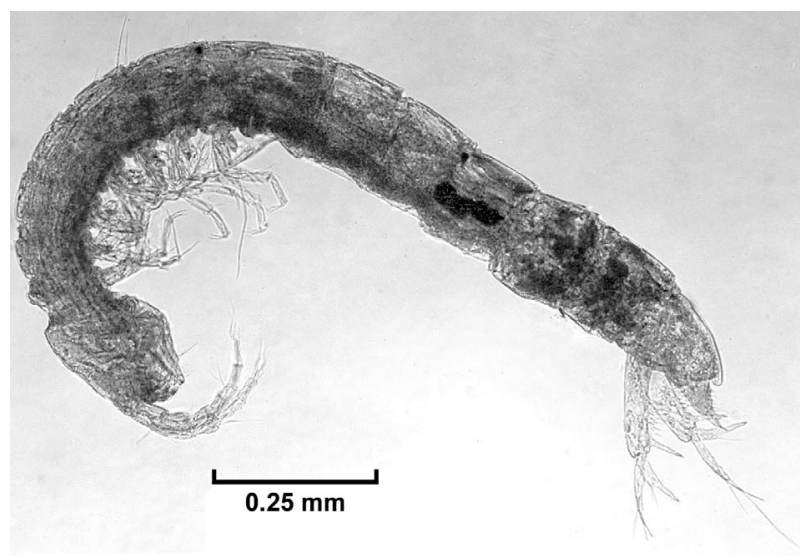

Fig. 1.- Photograph of Iberobathynella (Espanobathynella) andalusica n. sp. female (optical microscope $10 \mathrm{X}$ ).

Fig. 1.- Fotografía óptica $(10 \mathrm{X})$ de una hembra de Iberobathynella (Espanobathynella) andalusica $\mathbf{n}$. sp. (Escala en $\mathrm{mm}$ ).

segmented, segment 1 with two terminal setae, one short and smooth, the other long and barbed; segment 2 with two terminal setae, one barbed, the other plumose; with ctenidia; endopod 4-segmented, segment 1 short and without setae; segment 2 with two groups of medial ctenidia and one plumose and one smooth seta; segment 3 with one tiny seta; last segment with one seta and two strong claws of different length. In all thoracopods the first segment of exopod is twice as long as the second and is similar to the first two segments of the endopod combined. Thoracopod 8 (Th. 8), male (figure $2 \mathrm{H}$ and $\mathrm{I}$ ): massive, almost square; basal region massive; inner lobe subrectangular and completely integrated into basal region, exceeding distal end of dentate lobe; basipod elongated with one short seta distally; endopod small, with two setae; exopod small with two small teeth; outer lobe not fused with basipod and almost triangular. Thoracopod 8, female paratype (figure $2 \mathrm{G}$ ): not very reduced and with smooth cuticle, with two terminal teeth. Dorsal margin of pleotelson (figure 3I): anal operculum pronounced; one barbed seta at each distolateral angle. Uropod (figure $3 \mathrm{H}$ ): sympod almost twice as long as of endopod and almost six times longer than wide, with eight similar barbed spines located on last two-thirds of segment, and one more distal spine twice longer than others; endopod longer than exopod, with two long barbed setae plus plumose seta; exopod with two 


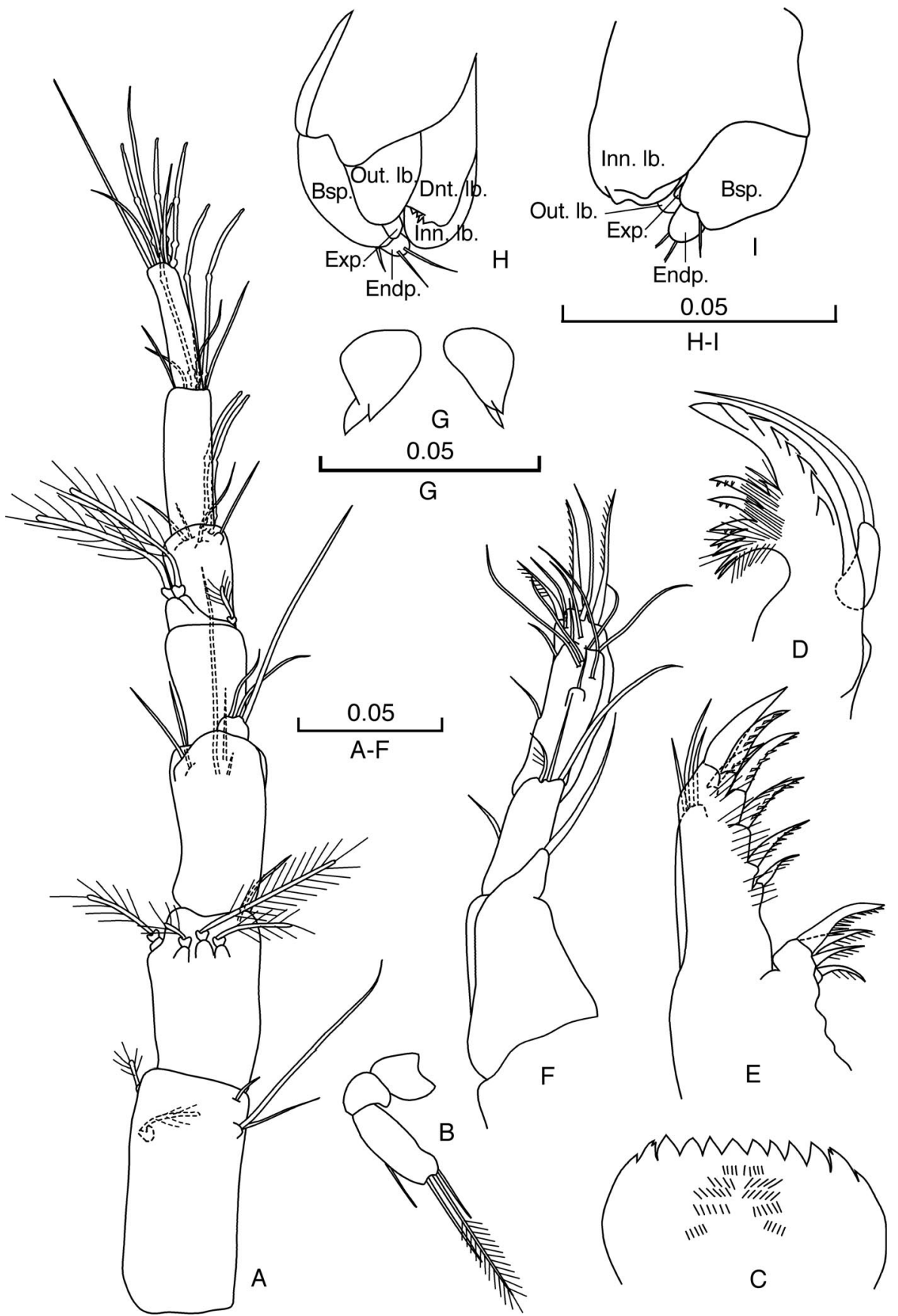

Fig. 2.- Iberobathynella (Espanobathynella) andalusica n. sp., male holotype. A: Antennule; B: Antenna; C: Labrum; D: Mandible; E: Maxillule; F: Maxilla; G: female Thoracopod 8 (ventral view); H: male Thoracopod 8 (latero-external view); I: male Thoracopod 8 (latero-internal view). Inner lobe (Inn. Lb.); basipod (Bsp.); dentate lobe (Dnt. Lb.); exopod (Exp.); basipod (Bsp.); outer lobe (Out. Lb.) and endopod (Endp.). (Scale in mm).

Fig. 2.- Iberobathynella (Espanobathynella) andalusica n. sp., holotipo macho. A: Anténula; B: Antena; C: Labro; D: Mandíbula; E: Maxílula; F: Maxila; G: pereiópodo 8 hembra (vista ventral); H: pereiópodo 8 macho (vista latero-externa); I: pereiópodo 8 macho (vista latero-interna). Lóbulo interno (Inn. Lb.); basipodio (Bsp.); lóbulo dentado (Dnt. Lb.); exopodio (Exp.); lóbulo externo (Out. Lb.) y endopodio (Endp.) (Escala en mm). 


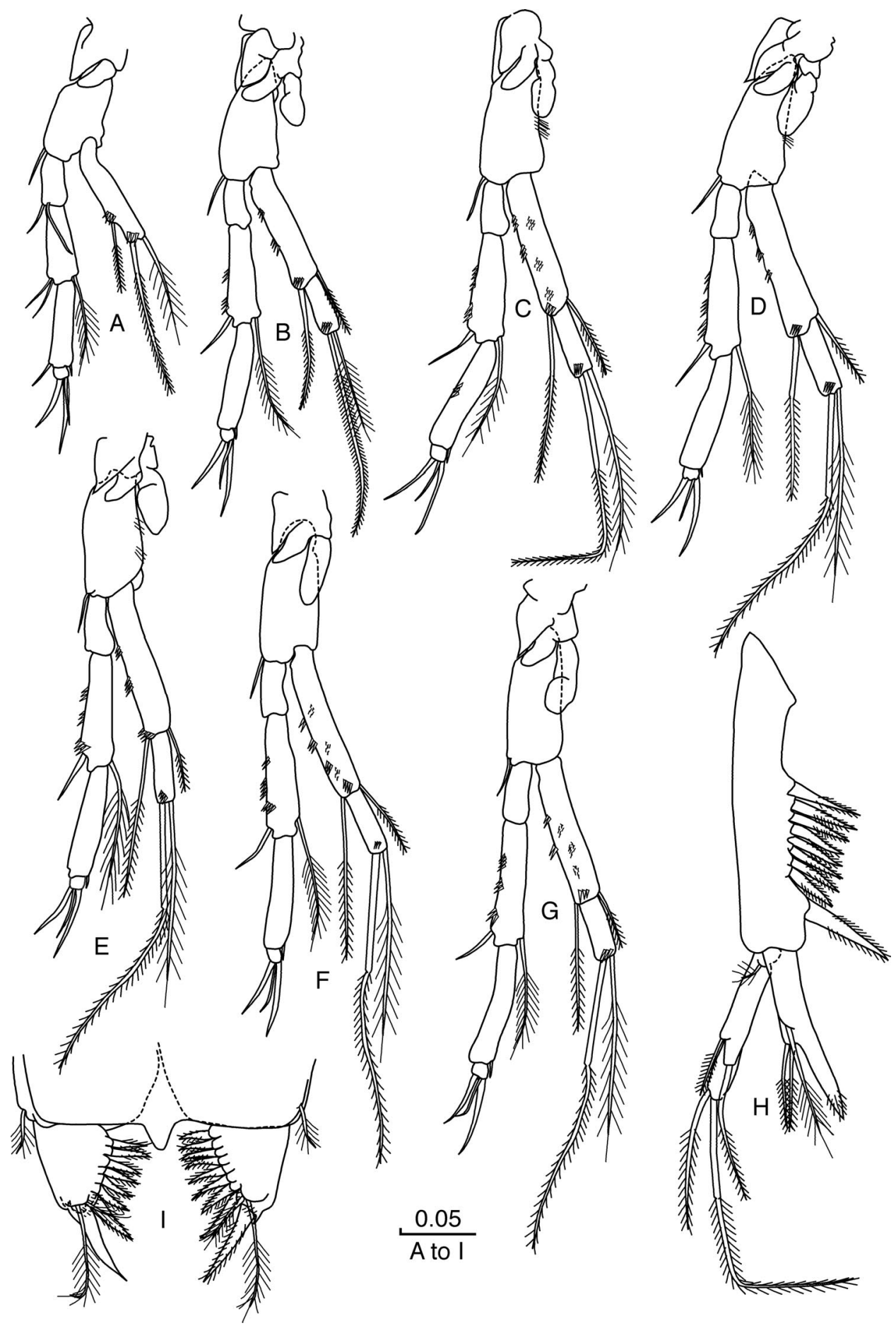

Fig. 3.- Iberobathynella (Espanobathynella) andalusica n. sp., male holotype. A: Thoracopod 1; B: Thoracopod 2; C: Thoracopod 3; D: Thoracopod 4; E: Thoracopod 5; F: Thoracopod 6; G: Thoracopod 7; H: uropod (latero-external view); I: Pleotelson and furca (dorsal view). (Scale in $\mathrm{mm}$ ).

Fig. 2.- Iberobathynella (Espanobathynella) andalusica n. sp., holotipo macho. A: pereiópodo 1; B: pereiópodo 2; C: pereiópodo 3; D: pereiópodo 4; E: pereiópodo 5; F: pereiópodo 6; G: pereiópodo 7; H: urópodo (vista latero-externa) e I: Pleotelson y furca (vista dorsal). (Escala en $\mathrm{mm}$ ). 


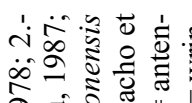

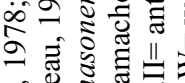

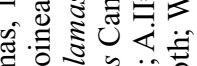

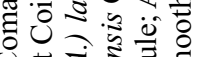

¿

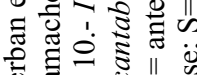

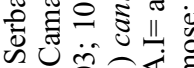

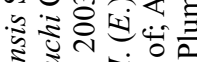

ฐ

区'.

i.

- 2 ن $\dot{0} \infty$

ญ -

పे

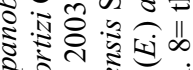

约

-

ช

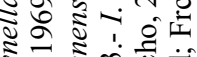

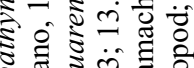

ప

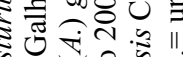

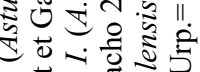

๘্்

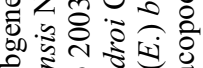

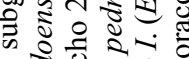

๑ ‡

ப

ฮิ ङ

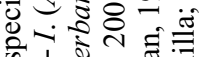

के

d্்

ช

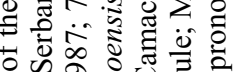

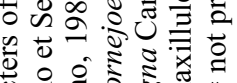

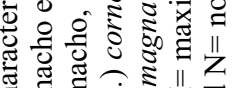

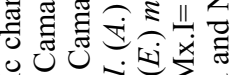

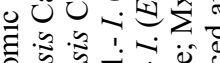

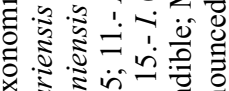

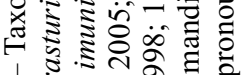

|.

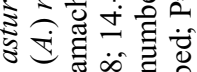

ชน

ชิ

वृ

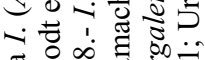

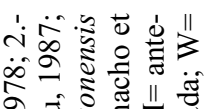

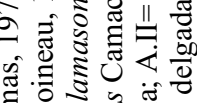

ठ을

0

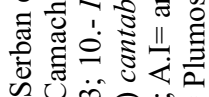

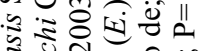

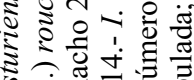

可诺的言

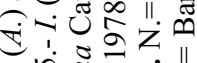

in

1. 200

(1) 8 .

卷

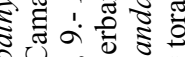

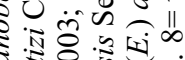

는

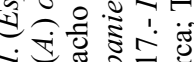

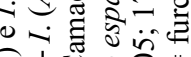

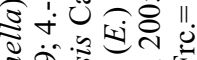

今.

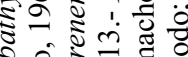

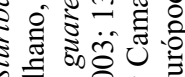

ज्ञ त्र ते है।

- 4 원

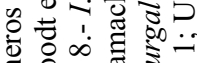

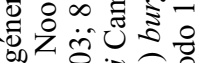

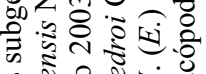

ติ ปㅇํㄴ

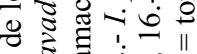

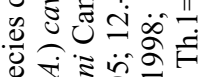

¿ 3 的?

क्षे हैं है

चٓ

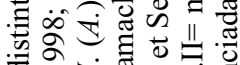

品

\&

क

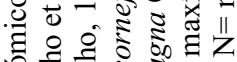

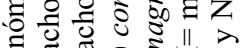

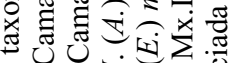

o.

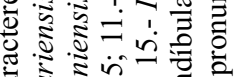

ฮั

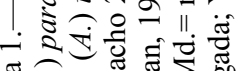

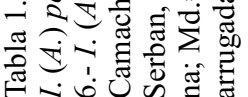

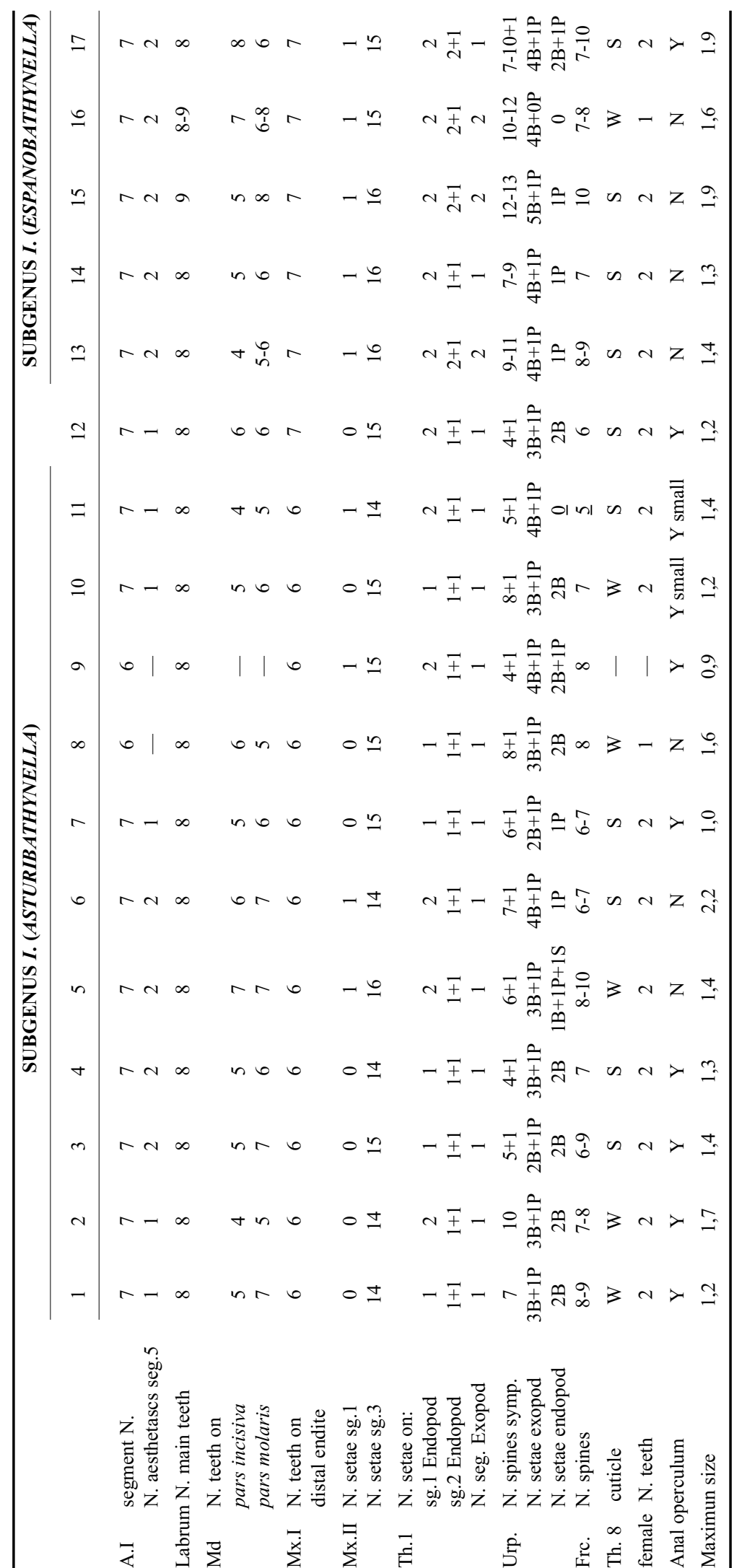

Graellsia, 63(2), Diciembre 2007, pp. 339-347 — ISSN: 0367-5041 


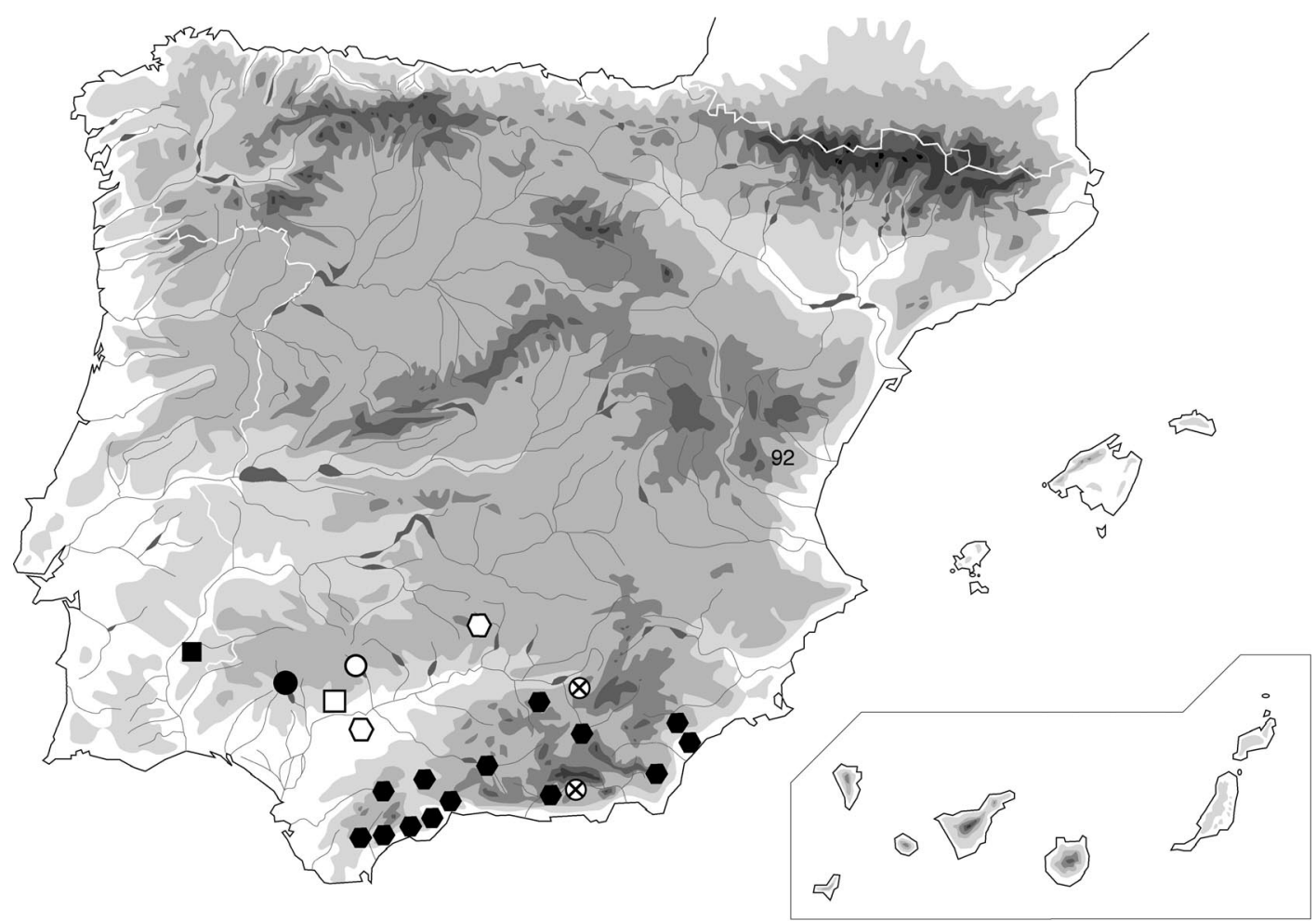

Paraiberobathynella fagei
Hexabathynella minuta
Hexabathynella sevillaensis
Iberobathynella (Iberobathynella) paragracilipes
$\square$ Iberobathynella (Asturibathynella) celiana
$\square$ Iberobathynella (Espanobathynella) andalusica n.sp.
$\bigotimes$ Hexaiberobathynella mateusi

Fig. 4.- Distribution of species of Parabathynellidae in Andalusia (Spain).

Fig. 4.- Distribución de las especies de la familia Parabathynellidae en Andalucía (España).

terminal and two subterminal barbed setae, and one basal plumose seta. Furca (figure 3I): with eight to nine barbed spines (two terminal ones slightly longer and thicker than rest); two plumose setae, one long and other shorter, disposed dorsal and distally.

Variability. The female is similar to the male, except for the thoracopod 8 . The variability affects: the number of teeth on the pars molaris of the Md. (the specimens studied have between seven and nine teeth); the number of spines on the sympod of the uropod (seven to eleven); and the number of spines on the furca (seven to ten).

ETymology. The species name, Iberobathynella (Espanobathynella) andalusica n. sp., is derived from the Andalusia region, in the South of Spain, where the species was discovered.

DisTRIBUTION. The new species of Iberobathynella was found in Sevilla and Córdoba provinces, where no other species of the subgenus Espanobathynella occur (Camacho, 2003b). To date, 22 species of this endemic genus are known in the Iberian Peninsula, mainly concentrated in the north and west; in the south and in the southeast portions it is known from two localities only.

The subgenus Espanobathynella was restricted, to date, to a small part of Cantabria and Asturias (Eastern part of Asturias, Picos de Europa and Sierra de la Collada, between Asturias and Cantabria) and North of Burgos (see Camacho, 2005b). The disco- 
very of the new species in South Spain broadens the distribution range of the subgenus. There are five additional species of Parabathynellidae in Andalusia (see Figure 4): I. (I.) paragracilipes Camacho \& Serban, 1998 (Huelva), I. (A.) celiana Camacho, 2003 (Sevilla), Hexaiberobathynella mateusi (Galhano, 1967) (Jaén and Granada), Paraiberobathynella fagei (Delamare Deboutteville \& Angelier, 1950) (Málaga, Almería, Cádiz, Jaén and Granada), Hexabathynella minuta (Noodt \& Galhano, 1969) (Sevilla) and Hexabathynella sevillaensis Camacho, 2005 (Sevilla).

REMARKS. The new species belongs to the subgenus Espanobathynella Camacho et Serban, 1998 (see Table 1). It has seven teeth on the distal endite of the maxillule combined with: one seta on segment one of the Mx.II; two setae on segment one and two and three setae on segment 1 and 2, respectively, on the endopod of Th. 1; no seta developed on segment 1 of the endopodod of Ths. 2 to 7; and the external lobe of male Th 8 has a main axis sloping. Three characters of the original diagnosis of the subgenus (v. Camacho et Serban, 1998) have to be modified to incorporate the new species: pars incisiva of $\mathrm{Md}$ with 4 to 8 teeth, anal operculum pronounced or not, and endopod of uropod with 0 , 1 or 3 setae.

Iberobathynella (Espanobathynella) andalusica n. sp shows three unique characters in the subgenus: anal operculum pronounced; three setae on the endopod of the uropod, and 8 teeth on the pars incisiva of Md.

The combination of setae on the endopod of the uropod of the new species (two barbed and one plumose), unique in I. (Espanobathynella) subgenus, is very frequent between the five species of the subgenus I. (Iberobathynella), but appear only in a species of the $I$. (Asturibathynella) subgenus, $I$. (A.) celiana.

The new species and I. (E.) burgalensis have the same number of teeth on the pars molaris of the Md. (6) and the same number of setae on the third segment of the MxII (15 only) (see Table 1). I. (E.) andalusica $\mathrm{n}$. sp has more teeth on the pars incisiva of the Md. (8) than any other species in the subgenus and similar number to other species of the I. (Iberobathynella) subgenus. The new species has only one segment on the exopod of the first thoracopod, as $I$. (E.) cantabriensis. I. (E.) andalusica $\mathrm{n}$. $\mathrm{sp}$ has the distal spine of the sympod of the uropod longer than the other as in $I$. (E.) espaniensis. Other characters shared between the new species and other members of the subgenus are summarized in table 1.

The new species is easily recognized based on the combination of the character states shown in table 1. In addition, the overall appearance and size of the lobes of the male thoracopod 8 are also diagnostic.

\section{ACKNOWLEDGEMENTS}

We gratefully thank C. Puch, A. G. Valdecasas, J. Rodríguez, M. Peláez, D. Jaume and N. Coineau who helped us in different ways. We thank Mark Creb who helped us with the English translations. This work was supported by project CGL200502217/BOS and Convenio Junta de Castilla y León and CSIC.

\section{References}

CAMACHO, A.-I., 1992. Sampling the subterranean biota (aquatic environment). In: A.I. Camacho (ed.). The Natural History of Biospeology, Monografia 7 del Museo Nacional de Ciencias Naturales de Madrid, CSIC. Madrid: 135-168.

CAMACHO, A.-I., 2003a. Four new species of groundwater crustaceans (Syncarida, Bathynellacea, Parabathynellidae) endemic to the Iberian Peninsula. Journal of Natural History, 37: 2885-2907.

CAMACHO, A.-I., 2003b. An overview of the distribution of the Parabathynellidae (Crustacea, Syncarida, Bathynellacea) on the Iberian Peninsula and Balearic Islands. Graellsia, 59(1): 63-78.

CAmacho, A.-I., 2005a. Expanding the taxonomic conundrum: three new species of groundwater crustacean (Syncarida, Bathynellacea, Parabathynellidae) endemic to the Iberian Peninsula. Journal of Natural History, 39(21): 1819-1838.

CAMACHO, A.-I., 2005b. One more pieces in the genus puzzle: a new species of Iberobathynella Schminke, 1973 (Syncarida, Bathynellacea, Parabathynellidae) from the Iberian Peninsula. Graellsia, 61(1): 123-133.

CAmacho, A.-I., 2006. An annotated checklist of the Syncarida (Crustacea, Malacostraca) of the world. Zootaxa 1374: 1-54.

CAmacho, A.-I. \& Serban, E., 1998. Tribu des Iberobathynellini nov. Diagnoses des taxa nouveaux (Parabathynellidae, Bathynellacea, Podophallocarida). Travaux de l'Institut de Spéologie Emile Racovitza, [1995], XXXIV: 15-75.

CAmacho, A.-I. \& Serban, E., 2000. Revisión del grupo Iberobathynella (Iberobathynella) Schminke, 1973 (Crustacea, Syncarida, Parabathynellidae) endémico de la Península Ibérica. Graellsia, 56: 35-48.

Camacho, A.-I., Serban, E. \& Guil, N., 2000. Phylogenetical review and biogeographic remarks on 
the interstitial and subterranean freshwater iberobathynels (Crustacea, Syncarida, Parabathynellidae). Journal of Natural History, 34: 563-585.

Cvetkov, L., 1968. Un filet phréatobiologique. Bulletin de l'Institut de Zoologie et Musée de l'Académie Bulgare des Sciences, Sofia, 27: 215-218.

SCHMinKe, H.-K., 1973. Evolution, System und Verbreitungsgeschichte der Familie Parabathynellidae (Bathynellacea, Malacostraca). Akademie der Wissenschaften und der Literatur Mainz, MathematischNaturwissenschaftliche Klasse, Mikrofauna des Meeresboden, 24: 1-192.
Serban, E. \& Comas i Navarro, J.-C., 1978. Contribution à la connaissance du genre Iberobathynella Schminke: I. asturiensis $\mathrm{n}$. sp. et I. espaniensis n. sp., nouvelles espèces d'Espagne (Bathynellacea, Parabathynellidae). Travaux de l'Institut de Spéologie "Emile Racovitza", XVII: 13-37.

Recibido, 18-X-2007

Aceptado, 28-XI-2007 Publicado, 27-XII-2007 